DOI: 10.18276/sip.2017.50/1-14

\title{
Iwona Markowicz*
}

Uniwersytet Szczeciński

\section{RYNEK PRACY W WOJEWÓDZTWIE ZACHODNIOPOMORSKIM NA TLE POLSKI}

\section{Streszczenie}

Współczesne teorie rynku pracy wskazują na regionalną niejednorodność tego rynku. Celem artykułu jest analiza przestrzennego zróżnicowania wskaźników rynku pracy w województwach Polski w 2016 roku, ze szczególnym wskazaniem pozycji województwa zachodniopomorskiego. $\mathrm{W}$ analizie tej zastosowano dwa podejścia: analizę stanu i analizę przepływów. Wyniki wskazują na słabą sytuację województwa zachodniopomorskiego z pewnymi pozytywnymi symptomami.

Słowa kluczowe: rynek pracy, województwa Polski, aktywność zawodowa, zatrudnienie, bezrobocie

\section{Wprowadzenie}

W Szczecinie 22 maja 2017 roku odbyła się konferencja „Sytuacja demograficzna województwa zachodniopomorskiego jako wyzwanie dla polityki społecznej i gospodarczej”, zorganizowana przez Rządową Radę Ludnościową (RRL) we współpracy z Wojewodą Zachodniopomorskim i Urzędem Statystycznym w Szczecinie. Udział w konferencji wzięli przedstawiciele uczelni, lokalnej administracji rządowej i samorządowej oraz pracownicy resortu statystyki publicznej. RRL zwraca uwagę

Adres e-mail: iwona.markowicz@wneiz.pl 
na potrzebę interdyscyplinarnego podejścia do procesów demograficznych zachodzących w naszym kraju. Dlatego też wystąpienia na konferencji dotyczyły sytuacji demograficznej województwa oraz związanych z tym zagadnieniem: ruchu naturalnego i wędrówkowego, rynku pracy, sytuacji rodzin, potencjału zdrowotnego, procesów starzenia się społeczeństwa. Omówiono wpływ zachodzących zmian demograficznych na gospodarkę i przyszłość regionu, a także podjęto próbę wskazania działań mogących zahamować negatywne tendencje. Szczecin jest czternastym miastem, w którym organizowana jest taka konferencja. Wnioski z całej Polski zbiera RRL (organ doradczy Prezesa Rady Ministrów w sprawach dotyczących zagadnień demograficznych i polityki ludnościowej), a podsumowaniem wszystkich spotkań będzie konferencja ogólnopolska. Jak podkreśliła J. Hrynkiewicz, przewodnicząca RRL, każde województwo ma swoją specyfikę, różni się od pozostałych regionów, a interdyscyplinarne podejście do procesów demograficznych pomoże w lepszym przygotowywaniu dla Rady Ministrów propozycji projektów, które poprawią jakość życia w Polsce. Wojewoda K. Kozłowski stwierdził, że jest to okazja dla samorządowców, którzy mogą próbować przełożyć wnioski płynące z badań naukowych na konkretne działania. Autorka prezentowała na omawianej konferencji sytuację na rynku pracy.

Praca jest nieodłącznym elementem analiz problemów społecznych w Polsce i na świecie. Nie można jej pominąć w kreowaniu działań zmierzających do rozwiązywania bądź ograniczania negatywnych skutków procesów społecznych (Hrynkiewicz, 2014). Z pracą, a właściwie z jej brakiem, związane są takie problemy, jak bezrobocie, ubóstwo, nierówności dochodowe, opóźnienie usamodzielnienia i stabilizacji życiowej młodego pokolenia, utrudnienia w zakładaniu rodzin i zmniejszenie dzietności. Brak pracy lub praca nisko opłacana to przyczyna rozrastania się „,szarej strefy" w gospodarce, zmniejszania się popytu gospodarstw domowych na towary i usługi, wzrostu emigracji zarobkowej. Rozległość problemów i dotkliwość skutków związanych z niedopasowaniem stron popytowej i podażowej pracy powodują duże zainteresowanie rynkiem pracy przez badaczy i polityków. Badania czasu trwania bezrobocia dostarczają informacji o jego determinantach, takich jak wiek, wykształcenie, płeć (Bieszk-Stolorz, Markowicz, 2016). Badanie zmian zachodzących na tym rynku jest ważne w kreowaniu odpowiedniej polityki.

Problemy związane z rynkiem pracy i konieczność ich rozwiązywania nie dotyczą jedynie Polski. Kraje członkowskie Unii Europejskiej zostały zobowiązane do realizacji celów Europejskiej Strategii Zatrudnienia, czyli pełnego zatrudnienia, polepszenia jakości i produktywności pracy oraz wzmocnienia spójności i integracji społecznej. Za pełne zatrudnienie przyjęto 75 -procentową stopę zatrudnienia dla 
osób w wieku 20-64 lata (Komisja Europejska, 2010). Dla Polski cel ten został wyznaczony także na bardzo wysokim poziomie wynoszącym $71 \%$.

Na rysunku 1 przedstawiono wartości wskaźnika zatrudnienia (wiek 20-64 lata) w latach 2002-2016 wraz z celem na 2020 rok dla Polski i Unii Europejskiej. Zwiększenie zatrudnienia jest jednym $\mathrm{z}$ założeń reform proponowanych $\mathrm{w}$ strategii Europa 2020 (Ministerstwo Gospodarki, 2016). Zaproponowany w niej model europejskiej społecznej gospodarki rynkowej ma obejmować wzrost inteligentny, zrównoważony i sprzyjający włączeniu społecznemu (aktywizacja zawodowa jak największej liczby osób). Wskaźnik zatrudnienia w Polsce zbliża się do wartości dla Unii Europejskiej, stopa bezrobocia zmniejszyła się, a udział aktywnych zawodowo ma tendencję rosnącą (rys. 2).

\section{Rysunek 1. Wskaźnik zatrudnienia w Polsce i Unii Europejskiej} w latach 2002-2016 i cel na 2020 rok (\%)

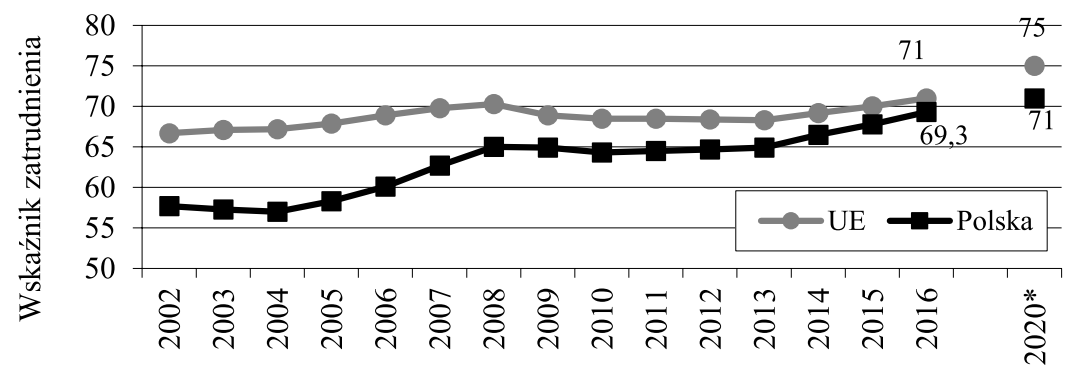

Źródło: opracowanie własne na podstawie danych Eurostatu.

Rysunek 2. Stopa bezrobocia (b) i udział aktywnych zawodowo (z) w Polsce i Unii Europejskiej w latach 2002-2016 (\%)
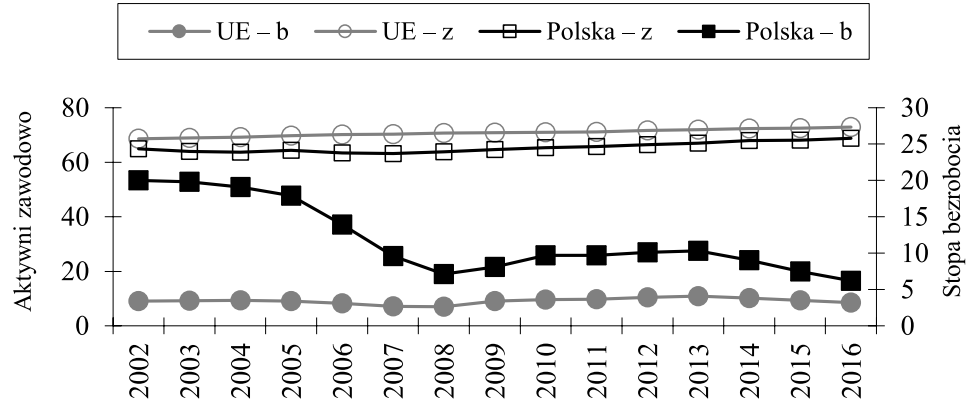

Źródło: opracowanie własne na podstawie danych Eurostatu. 
Należy zwrócić uwagę na obserwowane i przewidywane przemiany demograficzne wywołujące zarówno w Polsce, jak i w całej Unii Europejskiej procesy zmniejszania i starzenia populacji potencjalnych zasobów pracy. Według Kryńskiej (2012) starzenie się zasobów pracy wpływa na zmniejszenie elastyczności rynku pracy, natomiast w opinii Sowińskiej (2012) warunki gospodarki rynkowej dają szansę i sprzyjają rozwojowi, ale też mogą stwarzać zagrożenia. Za największe z nich, o najgroźniejszych następstwach społecznych, powszechnie uznawane jest bezrobocie. W literaturze podkreśla się duże znaczenie społeczno-ekonomiczne i polityczne zjawiska bezrobocia, jego negatywny wpływ na jakość życia osób poszukujących i nieznajdujących pracy oraz ich rodzin (Kwiatkowski, 2005; Bieszk-Stolorz, 2013). Wraz z czasem trwania bezrobocia postępuje zubożenie, marginalizacja i izolacja społeczna prowadzące do zjawiska wykluczenia. Stosując odpowiednie instrumenty polityki gospodarczej, państwo może wpływać na rynek pracy. Hrynkiewicz stwierdza, że Polska znalazła się w kryzysie demograficznym (Rządowa Rada Ludnościowa, 2016). Od 2012 roku obserwujemy ubytek rzeczywisty ludności. Jest on wynikiem niekorzystnych tendencji - zmniejszenia przyrostu naturalnego i zwiększenia migracji zagranicznych na pobyt stały. Przyśpieszeniu ulega także starzenie się ludności Polski (wzrost udziału ludności w wieku poprodukcyjnym, w tym również w wieku sędziwym - 80 lat i więcej). W raporcie RRL podkreślono kurczenie się zasobów pracy i jego negatywny wpływ na rozwój społeczno-gospodarczy kraju.

Powyższe argumenty wskazują na potrzebę prowadzenia analiz rynku pracy. $\mathrm{W}$ artykule zaprezentowano sytuację $\mathrm{w}$ województwie zachodniopomorskim na tle pozostałych województw w Polsce. Zastosowano analizy stanów i przepływów podstawowych charakterystyk związanych z zatrudnieniem i bezrobociem. Celem tak przeprowadzonej analizy jest wskazanie pozycji województwa zachodniopomorskiego.

\section{Zróżnicowanie przestrzenne rynku pracy}

Kreowane współcześnie teorie ekonomiczne dotyczące rynku pracy są modyfikacjami dorobku ekonomii głównego nurtu. Ekonomia alternatywna pozostaje w opozycji do tak zwanej ekonomii ortodoksyjnej (Ratajczak, 2005). Według teorii neoklasycznej (nawiązanie do poglądów Smitha), zgodnie z prawem Saya, podaż tworzy popyt. Mechanizm rynkowy w dłuższym okresie zapewnia równowagę pod warunkiem braku ingerencji z zewnątrz. Zgodnie z modelem doskonałej konku- 
rencji Pigou na rynku pracy przyjmuje się założenia, że pracodawcy i pracobiorcy mają pełną informację o płacach i możliwościach zatrudnienia, podejmują racjonalne decyzje, brak jest ograniczeń mobilności siły roboczej, a cena pracy stanowi mechanizm równoważenia popytu i podaży. Bezrobocie ma charakter dobrowolny i jest rezultatem ingerencji państwa i związków zawodowych. Neokeynesiści natomiast podkreślają nieelastyczność siły roboczej, sztywność płac oraz możliwość równowagi w gospodarce przy niepełnym zatrudnieniu. Uważają, że bezrobocie ma charakter przymusowy, a w jego zwalczaniu niezbędna jest ingerencja państwa poprzez aktywną politykę.

Teorie współczesne zawierają odmienne lub rozszerzone zbiory hipotez dotyczących występowania, powstawania i utrzymywania się nierównowagi na rynku pracy. W literaturze wskazuje się trzy podstawowe grupy takich hipotez (Knapińska, 2009). Pierwsza dotyczy czynników strukturalnych i instytucjonalnych jako odpowiedzialnych za powstawanie nierównowagi na rynku pracy - teoria segmentacji (ograniczenie mobilności siły roboczej stanowi istotny element wyjaśniający procesy tworzenia się i utrwalania nierównowagi na rynku pracy). Druga traktuje o nierównowadze spowodowanej długotrwałością procesów dostosowawczych na rynku pracy - teorie kapitału ludzkiego, naturalnej stopy bezrobocia, poszukiwań na rynku pracy (związek między ograniczeniami mobilności pracobiorców a nierównowagą na rynku pracy). Natomiast trzecia zakłada, że nierównowaga na rynku pracy może być spowodowana sztywnością płac - teoria płacy efektywnej (Kryńska, 2000; Jarmołowicz, Knapińska, 2011). Teorie te, w odróżnieniu od teorii głównego nurtu, podnoszą aspekt braku homogeniczności rynku pracy. Zarówno z licznych badań, jak i z analizy prezentowanej w artykule wynika, że w Polsce także występuje przestrzenne zróżnicowanie zjawisk na rynku pracy.

Jak zauważa Gołata (2004), popyt na pracę w ujęciu terytorialnym zmieniał się nierównomiernie. Badanie bezrobocia w Polsce ujęte jest w programie badań statystyki publicznej, a jego obserwacja, pomiar i analiza dają możliwość formułowania programów aktywnej polityki rynku pracy. Programy zatrudnienia mają sprzyjać ponownemu włączeniu bezrobotnych w proces pracy. Zatem aktywna polityka zmierza do aktywizacji zawodowej bezrobotnych, zmniejszenia niedopasowania strukturalnego, podniesienia produkcyjności siły roboczej i weryfikacji gotowości do pracy bezrobotnych (Wiśniewski, Zawadzki, 2010). W Polsce obserwacja zjawiska bezrobocia odbywa się poprzez rejestrację bezrobotnych w urzędach pracy oraz badanie BAEL. Obydwa podejścia różnią się zarówno definiowaniem osoby bezrobotnej, jak i sposobem zbierania informacji. W licznych analizach wymienia 
się ich zalety i wady. W przypadku bezrobocia rejestrowanego podkreśla się częsty brak gotowości do pracy osób zarejestrowanych, a w przypadku BAEL - odmowy udzielania odpowiedzi.

Miary stosowane $\mathrm{w}$ analizie rynku pracy w ujęciu przestrzennym są różnorodnie klasyfikowane (Gołata, 2004). Jednym z kryteriów może być rodzaj analizy. $\mathrm{W}$ artykule przedstawiona zostanie sytuacja województwa zachodniopomorskiego na tle pozostałych województw w następującym układzie:

a) analiza stanu (wskaźniki natężenia): współczynnik aktywności zawodowej (liczba aktywnych zawodowo/liczba ludności w wieku 15 lat i więcej), wskaźnik zatrudnienia (liczba pracujących/liczba ludności w wieku 15 lat i więcej), stopa bezrobocia (liczba bezrobotnych/liczba ludności aktywnej zawodowo);

b) analiza przepływów (strumieni): stopa odpływu z bezrobocia (liczba wyrejestrowanych bezrobotnych/liczba bezrobotnych w poprzednim okresie), stopa napływu do bezrobocia (liczba nowo zarejestrowanych bezrobotnych/ liczba aktywnych zawodowo).

\section{Analiza stanu rynku pracy - wskaźniki statystyczne}

Podstawowymi wskaźnikami natężenia zjawisk na rynku pracy są: współczynnik aktywności zawodowej (BAEL), wskaźnik zatrudnienia (BAEL) i stopa bezrobocia (BAEL lub rejestrowanego). W Polsce w 2016 roku wskaźniki te wynosiły odpowiednio: $56,2 \%, 52,8 \%, 6,2 \%$ i 8,3\%, a w województwach są zróżnicowane (rys. 3, 4, 7), co wynika ze zróżnicowania poziomu rozwoju społeczno-gospodarczego regionów, nierównomiernych zmian popytu na pracę, różnego nasilenia likwidowanych i prywatyzowanych przedsiębiorstw państwowych w okresie transformacji (Malarska, 2000; Gołata, 2004; Kotowska, Podogrodzka, 1995), a także ze zróżnicowanego poziomu przedsiębiorczości (liczba powstających i likwidowanych firm) (Markowicz, 2012). Oczywiście różnice na rynku pracy dotyczące podaży i popytu mogą być źródłem niedopasowań strukturalnych, a więc nawet rynek pracy w ogólnych liczbach zbilansowany może wykazywać znaczne poziomy bezrobocia (Góra, Sztanderska, 2006).

Wyniki zaprezentowane na rysunkach 3-7 pochodzą z badania BAEL przeprowadzonego przez GUS oraz z rejestrów prowadzonych przez powiatowe urzędy pracy. Badanie BAEL przeprowadzane jest metodą reprezentacyjną dla ludności w wieku 15 lat i więcej. Umożliwia ona uogólnianie wyników badania na populację generalną. 
Rysunek 3. Współczynnik aktywności zawodowej w województwach Polski w 2016 roku (\%)

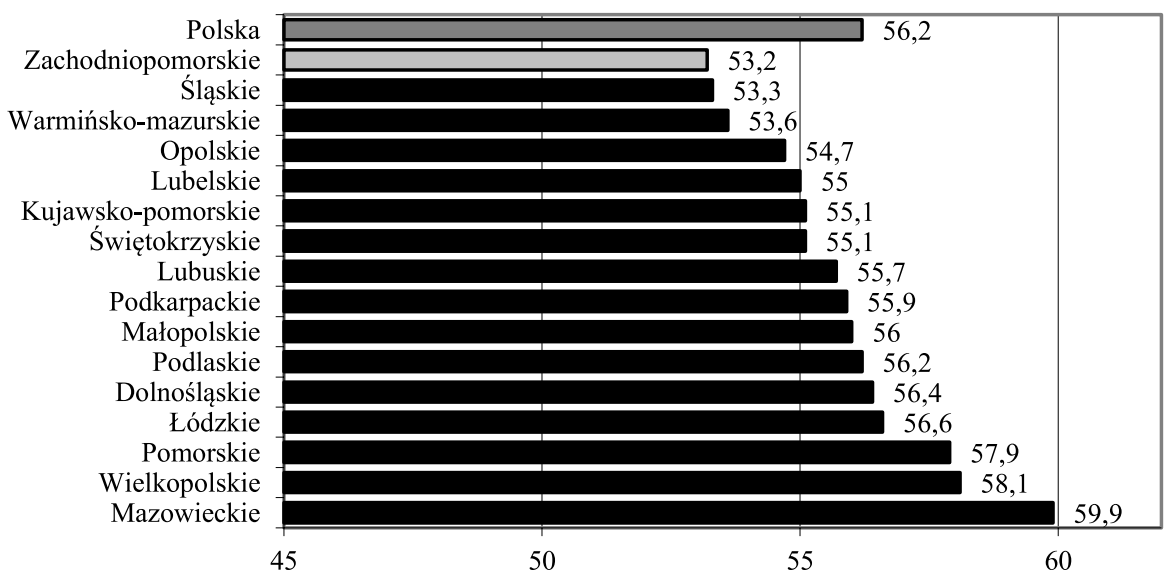

Źródło: opracowanie własne na podstawie danych: GUS, Bank Danych Lokalnych.

Rysunek 4. Wskaźnik zatrudnienia w województwach Polski w 2016 roku (\%)

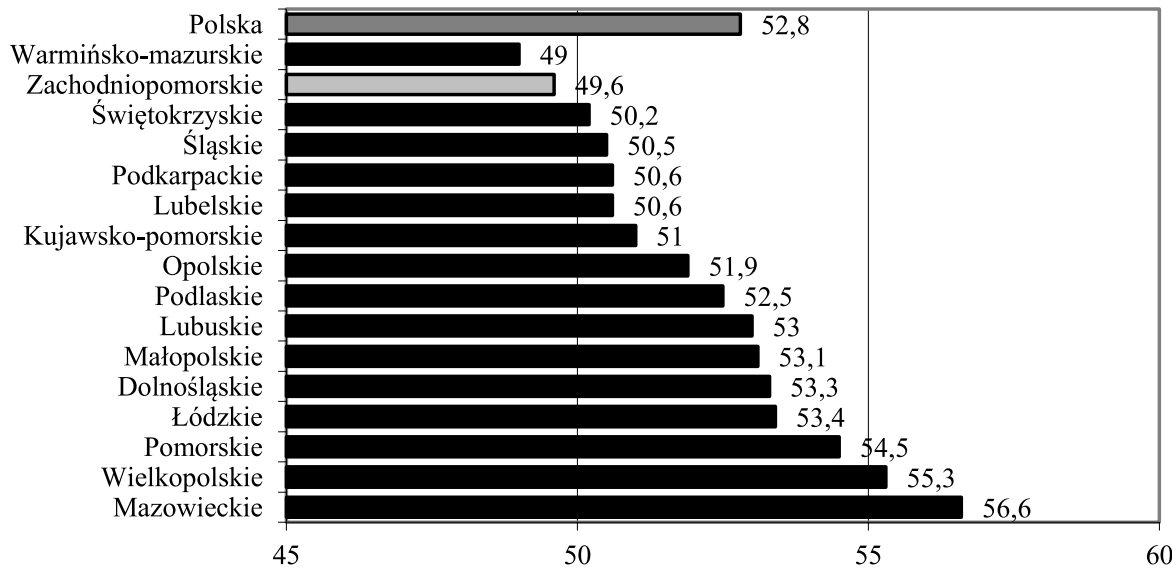

Źródło: opracowanie własne na podstawie danych: GUS, Bank Danych Lokalnych.

Analizując wskaźniki - współczynnik aktywności zawodowej i wskaźnik zatrudnienia (rys. 3-4) - należy stwierdzić, że sytuacja województwa zachodniopomorskiego na tle pozostałych województw Polski jest zła. Aktywność zawodowa jest tu najniższa, a pod względem wskaźnika zatrudnienia zajmuje ono drugie miejsce (po województwie warmińsko-mazurskim). Zatem zainteresowanie pracą jest sto- 
sunkowo niskie. Równocześnie analiza średniego miesięcznego wynagrodzenia w województwach w 2016 roku (od 3728,9 do 5300,7 zł) wskazuje na szóstą pozycję zachodniopomorskiego wśród województw o najwyższej średniej (4075,06zł).

Rysunek 5. Udział właścicieli i współwłaścicieli łącznie z pomagającymi członkami ich rodzin w liczbie pracujących ogółem w województwach Polski w 2015 roku (\%)

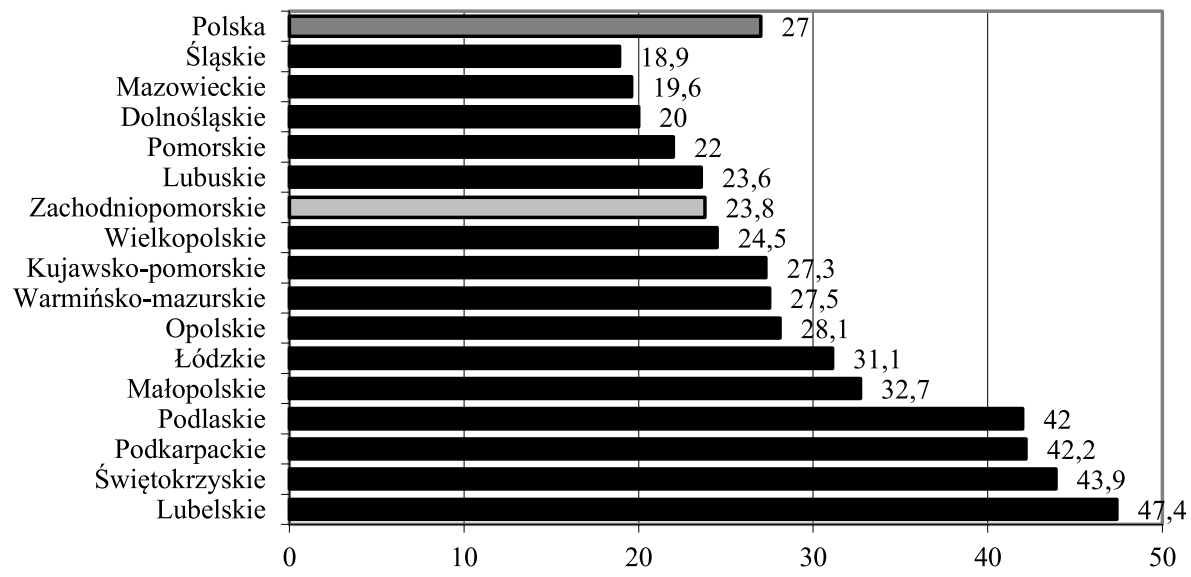

Źródło: opracowanie własne na podstawie danych: GUS, Bank Danych Lokalnych.

Rysunek 6. Stopa bezrobocia rejestrowanego w województwach Polski w 2016 roku (\%)

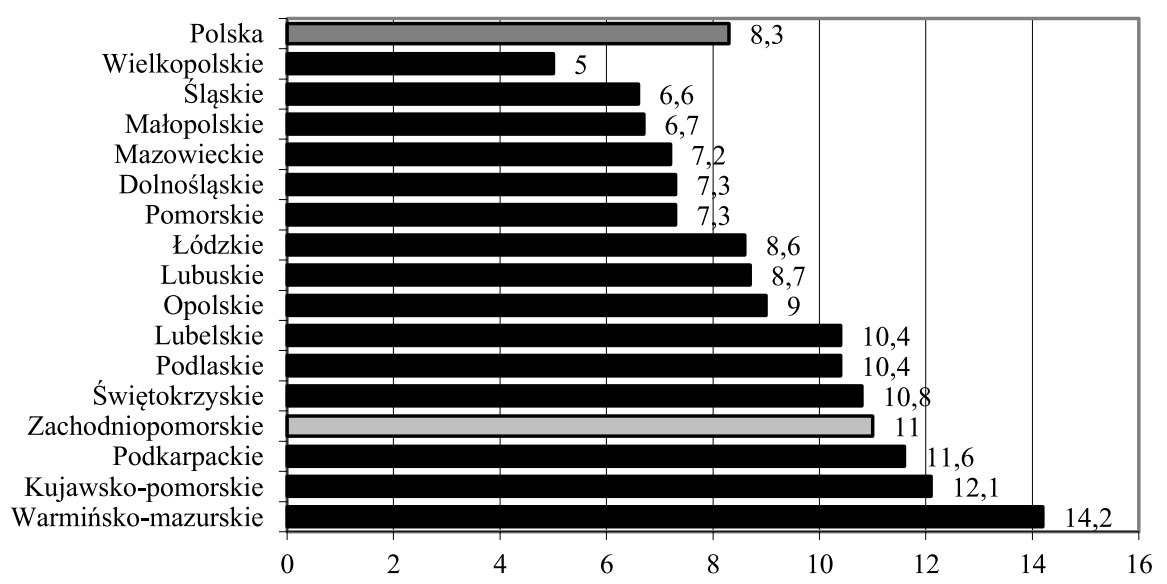

Źródło: opracowanie własne na podstawie danych: GUS, Bank Danych Lokalnych. 
Na rysunku 5 przedstawiono udział liczby właścicieli i współwłaścicieli, łącznie z pomagającymi członkami ich rodzin, w liczbie pracujących ogółem w województwach Polski w 2015 roku (\%). Wydaje się, że w województwie zachodniopomorskim istnieją jeszcze możliwości zakładania i prowadzenia własnych firm.

W województwie zachodniopomorskim równocześnie z niskim udziałem ludności aktywnej zawodowo występuje stosunkowo wysoka stopa bezrobocia. Biorąc pod uwagę bezrobocie rejestrowane, tylko trzy województwa (podkarpackie, kujawsko-pomorskie i warmińsko-mazurskie) mają wyższą stopę bezrobocia (rys. 6). W wielu opracowaniach podkreśla się, że osoby rejestrujące się jako bezrobotne nie zawsze faktycznie poszukują pracy, nie zmienia to jednak faktu, że nie pracują. Natomiast według wyników BAEL województwo zajmuje szóste miejsce wśród województw o najwyższej stopie bezrobocia. W dalszej części przedstawione zostaną podstawowe charakterystyki bezrobocia. W Polsce kobiety stanowią 53,3\% bezrobotnych. W województwach udział ten waha się od 45,6 do 60,0\%. Zachodniopomorskie z wartością 55,3\% znajduje się w środkowej części listy. W szczególnie trudnej sytuacji znajdują się osoby pozostające w bezrobociu 12 miesięcy i dłużej. W Polsce bezrobocie długotrwałe stanowi aż 40,7\% bezrobocia ogółem, a województwach waha sie od 33,1 do 46,0\%. Zachodniopomorskie z wartością 36,5\% zajmuje czwarte miejsce wśród województw z najniższym udziałem (po lubuskim, wielkopolskim i pomorskim). Ciekawą charakterystyką jest także wykształcenie bezrobotnych. Szczególną uwagę przywiązuje się tu do wykształcenia wyższego, które powinno pomagać w poszukiwaniu pracy. Wśród bezrobotnych w Polsce najwyższe wykształcenie miało w 2016 roku 13,3\% osób, a w województwach od 8,7 do $16,3 \%$. W województwie zachodniopomorskim udział ten jest stosunkowo niski i wynosi $10,8 \%$. W analizach bezrobocia ważne jest również uwzględnianie wieku osób rejestrujących się w urzędach pracy. Szczególną uwagę zwrócono na osoby najmłodsze, do 25 roku życia. Wchodzą one dopiero na rynek pracy i napotykają problemy związane ze znalezieniem zazwyczaj pierwszej pracy. Młodzi stanowią 13,4\% bezrobotnych w Polsce, a 11,9\% w województwie zachodniopomorskim. Jest to czwarta lokata wśród województw z najniższym odsetkiem.

Mając na uwadze znaczenie diagnostyczne omawianych wskaźników w analizie regionalnej, należy podkreślić, że liczba bezrobotnych jest ujmowana według miejsca zamieszkania, a liczba zatrudnionych według lokalizacji zakładu pracy, co może mieć wpływ na zniekształcenie wyników.

Wydaje się, że dobrym rozwiązaniem $\mathrm{w}$ analizie stanu jest porównywanie dwóch wskaźników (rys. 7). Umieszczając w układzie współrzędnych wskaźnik zatrudnienia na jednej osi i stopę bezrobocia na drugiej, utworzono cztery pola: 
- niski wskaźnik zatrudnienia i niska stopa bezrobocia - „mała aktywność zawodowa",

- niski wskaźnik zatrudnienia i wysoka stopa bezrobocia - „brak miejsc pracy",

- wysoki wskaźnik zatrudnienia i niska stopa bezrobocia - „dobra sytuacja”,

- wysoki wskaźnik zatrudnienia i wysoka stopa bezrobocia - „duża aktywność zawodowa".

W polu o stosunkowo niskiej stopie bezrobocia i wysokim wskaźniku zatrudnienia, nazwanym „dobra sytuacja”, znajduje się siedem województw (w najlepszej sytuacji wśród nich są mazowieckie i wielkopolskie). Zła sytuacja określona jest jako „brak miejsc pracy” i oznacza stosunkowo duże bezrobocie oraz małe zatrudnienie. W tym polu znajduje się również siedem województw, a wśród nich zachodniopomorskie. Pozostałe dwie części można uznać za neutralne, gdyż zarówno wskaźnik zatrudnienia, jak i stopa bezrobocia są stosunkowo niskie (,mała aktywność zawodowa”) lub wysokie („duża aktywność zawodowa”). W częściach tych znajduje się odpowiednio województwo śląskie i opolskie.

Rysunek 7. Wskaźnik zatrudnienia i stopa bezrobocia w województwach Polski w 2016 roku (przecięcie osi - wartości mediany)

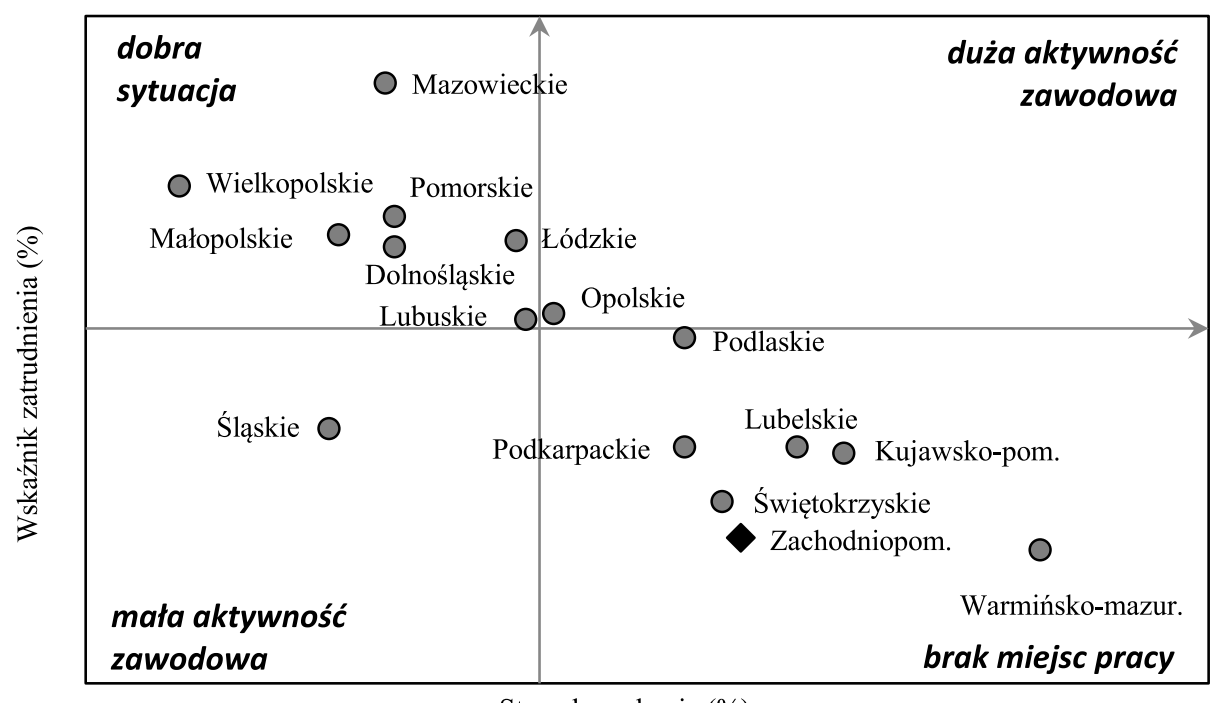

Stopa bezrobocia (\%) 


\section{Analiza przepływów na rynku pracy}

Analizę stanu zaprezentowaną w poprzednim podrozdziale można uzupełnić analizą przepływów umożliwiającą badanie zmian między stanami w danym okresie. Jak podkreślają Góra i Sztanderska (2006), aby zrozumieć sytuację na rynku pracy, ważne jest nie tylko stwierdzenie, ile osób znajduje się w danym stanie, lecz również ile do niego weszło i ile go opuściło. Dynamiczny rynek pracy cechują duże zmiany stanów, a na rynku stagnacyjnym stany są stabilne. Na każdym z nich trzeba stosować inną politykę. Wśród wskaźników opisujących przepływy na regionalnym rynku pracy wymienia się stopę napływu i stopę odpływu z bezrobocia rejestrowanego. Koncepcję łącznego ich przedstawiania podały Kotowska i Podogrodzka (1995), wyróżniając cztery grupy regionów:

- niski napływ i niski odpływ - sytuacja stagnacji,

- niski napływ i wysoki odpływ - sugestia możliwej poprawy,

- wysoki napływ i wysoki odpływ - duża ruchliwość wewnętrzna,

- wysoki napływ i niski odpływ - groźba pogorszenia sytuacji.

Podział ten wykorzystano w graficznym przedstawieniu relacji stóp przepływów w województwach Polski w 2016 roku (rys. 8).

Rysunek 8. Stopy przepływów bezrobocia rejestrowanego w województwach Polski

w 2016 roku (przecięcie osi - wartości mediany)

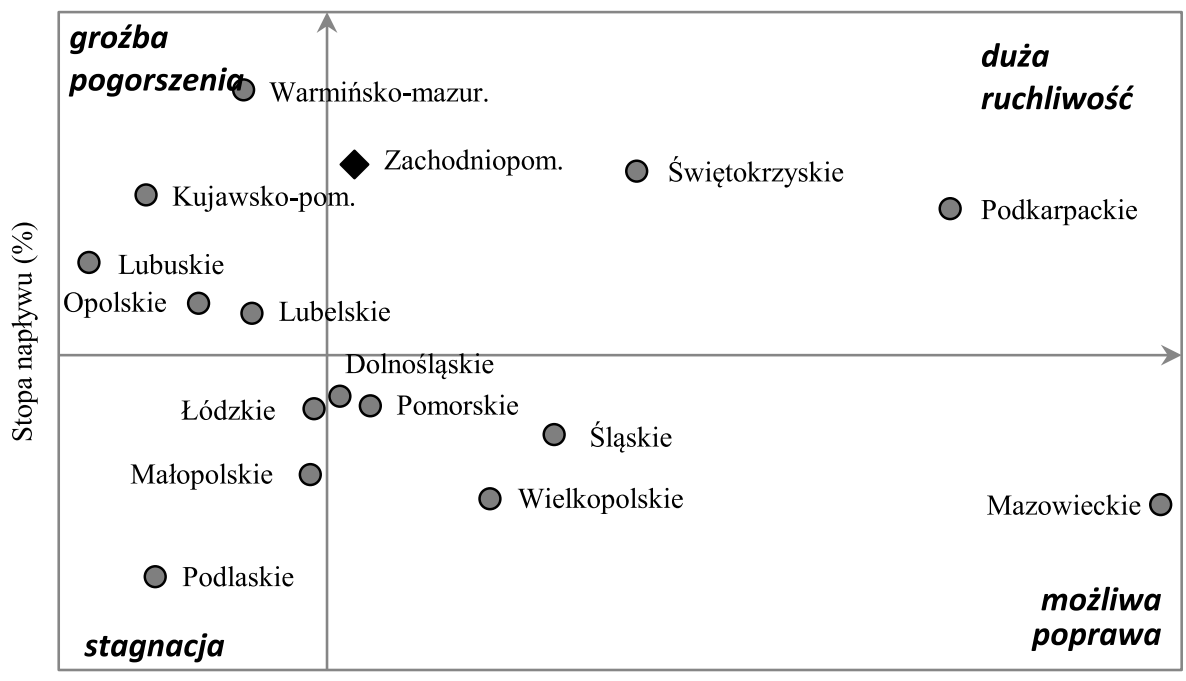

Stopa odpływu (\%)

Źródło: opracowanie własne. 
Analiza przepływów wzbogaca wyniki prowadzonych badań. Spośród siedmiu województw, które na rysunku 7 znajdowały się w ćwiartce „brak miejsc pracy” określającej złą sytuację na rynku pracy, dla trzech (warmińsko-mazurskie, kujawsko-pomorskie i lubuskie) istnieje „groźba pogorszenia” sytuacji. Województwa zachodniopomorskie, świętokrzyskie i podkarpackie znajdują się w ćwiartce „duża ruchliwość", co wskazuje na możliwości znalezienia miejsca pracy, a podlaskie w ćwiartce „stagnacja”, co sugeruje niepogarszanie stanu. W najlepszej sytuacji („możliwa poprawa”) znalazło się pięć województw: mazowieckie, wielkopolskie, śląskie, pomorskie i dolnośląskie. Należą one do grupy o niższej stopie bezrobocia i równocześnie stosunkowo niskiej stopie napływu.

Mając na względzie znaczenie diagnostyczne stosowanych wskaźników, należy zwrócić uwagę, że odpływ nie jest jednoznaczny z podjęciem pracy oraz że jedna osoba może wielokrotnie zmieniać stan w badanym okresie.

\section{Podsumowanie}

Celem badania była analiza przestrzennego zróżnicowania wskaźników rynku pracy w województwach Polski w 2016 roku, ze szczególnym wskazaniem pozycji województwa zachodniopomorskiego. Zastosowano rodzaje analiz: stanu i przepływów. Wyniki wskazują na słabą sytuację województwa zachodniopomorskiego z pewnymi pozytywnymi symptomami. O złej sytuacji świadczy najniższy współczynnik aktywności zawodowej, druga z najniższych wartości wskaźników zatrudnienia, czwarta z najwyższych wartości stopy bezrobocia (grupa województw określona jako „brak miejsc pracy”). Do pozytywnych symptomów można zaliczyć średni udział kobiet wśród bezrobotnych oraz stosunkowo niskie udziały długotrwale bezrobotnych, bezrobotnych z wykształceniem wyższym i bezrobotnych w wieku do 25 lat, a także wysokie stopy napływu i odpływu bezrobotnych (grupa województw o „dużej ruchliwości na rynku pracy”). 


\section{Literatura}

Bieszk-Stolorz, B. (2013). Analiza historii zdarzeń w badaniu bezrobocia. Szczecin: Volumina.pl.

Bieszk-Stolorz, B., Markowicz, I. (2016). Młodzi na rynku pracy w Szczecinie - tablice trwania w bezrobociu. Metody Ilościowe w Badaniach Ekonomicznych (Quantitative Methods in Economics), XVII (3), 108-119.

Gołata, E. (2004). Estymacja pośrednia bezrobocia na lokalnym rynku pracy. Poznań: Wyd. AE w Poznaniu.

Góra, M., Sztanderska, U. (red.) (2006). Wprowadzenie do analizy lokalnego rynku pracy. Przewodnik. Warszawa: Departament Analiz Ekonomicznych i Prognoz.

Hrynkiewicz, J. (2014). Problem pracy kluczem do rozwiązania kwestii społecznej. W: J. Hrynkiewicz (red.), Praca i płaca, Państwo i rynek (s. 11-29). Warszawa: ISNS Uniwersytetu Warszawskiego.

https://bdl.stat.gov.pl (10.04.2017).

http://ec.europa.eu/eurostat/web/lfs/data/database (10.04.2017).

Jarmołowicz, W., Knapińska, M. (2011). Współczesne teorie rynku pracy a mobilność i przepływy pracowników w dobie globalizacji. Zeszyty Naukowe Polskiego Towarzystwa Ekonomicznego, 9, 123-144.

Knapińska, M. (2009). Przepływy pracowników w świetle makro- i mikroekonomicznych teorii rynku pracy. W: T. Bernat (red.), Teoretyczne i praktyczne aspekty funkcjonowania gospodarki (s. 176-187). Szczecin: PrintGroup.

Komisja Europejska (2010). EUROPA 2020. Strategia na rzecz inteligentnego i zrównoważonego rozwoju sprzyjającego włączeniu społecznemu. Bruksela, 3.3.2010KOM(2010) 2020.

Kotowska, I., Podogrodzka, M. (1995). Przestrzenne zróżnicowanie rynku pracy w Polsce 1990-94. W: U. Sztanderska (red.), Rynek pracy w Polsce 1993-94 (s. 56-68). Warszawa: Raport IPiSS nr 9.

Kryńska, E. (2000). Mobilność zasobów pracy w wybranych teoriach rynku pracy. W: E. Kryńska (red.), Mobilność zasobów pracy (s. 5-32). Warszawa: Instytut Pracy i Spraw Socjalnych.

Kryńska, E. (2012). Wdrażanie koncepcji elastyczności i bezpieczeństwa na rynku pracy w warunkach przemian demograficznych. Studia Ekonomiczne, 103, 195-202.

Kwiatkowski, E. (2005). Bezrobocie. Podstawy teoretyczne. Warszawa: Wydawnictwo Naukowe PWN.

Malarska, A. (2000). Bezrobocie w Polsce w ujęciu regionalnym. Studium statystyczne. Łódź: Wyd. UŁ.

Markowicz, I. (2012). Statystyczna analiza żywotności firm. Szczecin: Wyd. Naukowe US.

Ministerstwo Gospodarki (2016). Krajowy Program Reform, Europa 2020. Pobrane z: www. mg.gov.pl (10.04.2017).

Ratajczak, M. (red.) (2005). Współczesne teorie ekonomiczne. Poznań: Wyd. AE w Poznaniu. 
Rządowa Rada Ludnościowa (2016). Sytuacja demograficzna Polski. Raport 2015-2016. Warszawa.

Sowińska, A. (2012). Samobójstwo jako konsekwencja niskiej jakości życia w sytuacji bezrobocia. Studia Ekonomiczne, 98, 163-177.

Wiśniewski, Z., Zawadzki, K. (red.) (2010). Aktywna polityka rynku pracy w Polsce w kontekście europejskim. Toruń: WUP, UMK.

\title{
LABOUR MARKET IN THE ZACHODNIOPOMORSKIE VOIVODESHIP \\ ON THE POLISH BACKGROUND
}

\begin{abstract}
Contemporary theories of labour market shows on regional heterogeneity of this market. The aim of the study was to analyze the spatial differentiation of labour market indicators in the voivodeship of Poland in 2016, with particular reference to the Zachodniopomorskie Voivodeship. Two approaches were used in this analyze: condition analyze, flows analyze. The results indicate a weak situation in the Zachodniopomorskie Voivodeship with some positive symptoms.
\end{abstract}

Translated by Iwona Markowicz

Keywords: labour market, voivodeship of Poland, economically activity, employment, unemployment

JEL Codes: E24, J01, J20 